\title{
MODEL DAMPAK DAN KEBERLANJUTAN PARIWISATA DI PULAU MERAH KABUPATEN BANYUWANGI
}

\author{
Aprilia Divi Yustita \\ Politeknik Negeri Banyuwangi \\ aprilia.divi@poliwangi.ac.id \\ Siska Aprilia Hardiyanti \\ Politeknik Negeri Banyuwangi \\ siska_aprilia3@poliwangi.ac.id \\ Ayu Purwaningtyas \\ Politeknik Negeri Banyuwangi \\ Ayu.purwaningtyas@poliwangi.ac.id
}

\begin{abstract}
Banyuwangi is a region that actives in developing the tourism sectors because Banyuwangi has great potential of natural resources. The efforts of Banyuwangi local government implicate to the tourist amount visiting the tourism destination in Banyuwangi. Pulau Merah is one of the favorite destinations in Banyuwangi with high visitation rate. As the effect of various tourism activity in the region, the surrounding environment of tourism destination will gain the effect of tourism activity. The effects of tourism activity are such as bringing the economics values from economical aspect, socio culture, and environment. The best management of tourism object is always based on the achievement of sustainable tourism. This research discusses the effect and sustainable tourism model in Red Island. The used statistics analysis technique here is Structural Equation Model (SEM) by using AMOS software. The result of this research shows that the model fulfills the qualification of SEM assumption and qualifies the criteria of eligibility model.
\end{abstract}

Keywords: Tourism Effect, Sustainable Tourism, Structural Equation Model

\section{Pendahuluan}

Sektor pariwisata di Kabupaten Banyuwangi saat ini sedang fokus untuk terus dikembangkan. Hal ini dikarenakan Banyuwangi memiliki potensi sumber daya alam yang besar sehingga dapat dijadikan sebagai daerah tujuan wisata. 
Sebagai akibat dari pembangunan pariwisata, maka lingkungan sekitar destinasi akan mendapatkan dampak dari berbagai aktivitas kepariwisataan yang ada. Kondisi ideal yang diharapkan dari kehadiran pariwisata yaitu pariwisata mendapatkan dukungan positif dari lingkungan dan lingkungan mendapatkan dampak positif dari kepariwisataan (Sunaryo, 2013).

Usaha pengembangan pada sektor pariwisata di Banyuwangi berimplikasi pada kenaikan jumlah wisatawan yang datang berkunjung ke berbagai destinasi wisata. Hal ini dibuktikan dengan adanya peningkatan jumlah wisatawan dari tahun ke tahun selama periode tahun 2013 sampai dengan 2017.

Tabel 1. Jumlah Kunjungan Wisatawan ke Banyuwangi Tahun 2013 - 2017

\begin{tabular}{|c|c|c|c|c|c|}
\hline Jenis & Tahun & Tahun & Tahun & Tahun & Tahun \\
\hline Wisatawan & $\begin{array}{l}2013 \\
\text { (orang) }\end{array}$ & $\begin{array}{l}2014 \\
\text { (orang) }\end{array}$ & $\begin{array}{l}2015 \\
\text { (orang) }\end{array}$ & $\begin{array}{l}2016 \\
\text { (orang) }\end{array}$ & $\begin{array}{l}2017 \\
\text { (orang) }\end{array}$ \\
\hline Nusantara & 1.057 .952 & 1.464 .948 & 1.926 .179 & 4.022 .449 & 4.832 .999 \\
\hline Mancanegara & 10.462 & 30.681 & 46.214 & 77.139 & 98.970 \\
\hline Total & 1.068 .414 & 1.495 .629 & 1.972 .393 & 4.099 .588 & 4.931 .969 \\
\hline
\end{tabular}

Berdasarkan tabel 1 dapat dilihat bahwa peningkatan terjadi setiap tahun, akan tetapi peningkatan tertinggi terjadi pada tahun 2016 baik untuk wisatawan nusantara maupun mancanegara.

Salah satu objek wisata di Banyuwangi yang memiliki tingkat kunjungan wisatawan yang cukup tinggi adalah Pulau Merah. 
Tabel 2. Jumlah Kunjungan Wisatawan ke Pulau Merah Tahun 2014 - 2018

\begin{tabular}{llllll}
\hline Jenis & Tahun & Tahun & Tahun & Tahun & $\begin{array}{l}\text { Tahun } \\
\text { Wisatawan }\end{array}$ \\
& 2014 & 2015 & 2016 & 2017 & 2018 \\
& (orang) & (orang) & (orang) & (orang) & (orang) \\
\hline Nusantara & 336.431 & 377.375 & 281.780 & 178.871 & 173.464 \\
\hline Mancanegara & 5.048 & 6.381 & 3.620 & 3.064 & 6.528 \\
\hline Total & $\mathbf{3 4 1 . 4 7 9}$ & $\mathbf{3 8 3 . 7 5 6}$ & $\mathbf{2 8 5 . 4 0 0}$ & $\mathbf{1 8 1 . 9 3 5}$ & $\mathbf{1 7 9 . 9 9 2}$ \\
\hline
\end{tabular}

Berdasarkan tabel 2 diketahui bahwa kunjungan wisatawan selama lima tahun terakhir menunjukkan kondisi yang fluktuatif. Menurut (Butler, 2011) dalam (Dwipayana, dkk., 2018) perubahan jumlah kunjungan wisatawan yang fluktuatif berkaitan dengan dinamika destinasi dan perubahan selera wisatawan sebagai konsumen. Pulau Merah sebagai objek wisata unggulan di Banyuwangi bukanlah objek wisata baru. Pulau Merah secara resmi dikelola oleh Perhum Perhutani, akan tetapi dalam menjalankan kegiatan pengelolaannya dibantu oleh masyarakat sekitar yang tergabung dalam anggota Kelompok Masyarakat (Pokmas). Keterlibatan masyarakat tersebut diwujudkan dalam berbagai aktifitas dalam kegaiatan kepariwisataan.

Pariwisata berkelanjutan (sustainable tourism) merupakan konsep pariwisata yang penting untuk diperhatikan. Hal ini dikarenakan pariwisata berkelanjutan sangat memperhatikan dampak dari kegiatan pariwisata dalam segi ekonomi, sosial, dan lingkungan, baik saat ini maupun di masa yang akan datang. Ditinjau dari segi pariwisata sebagai usaha, maka usaha yang baik adalah yang dapat melindungi aset penting pariwisata tidak hanya untuk saat ini tetapi juga di masa mendatang. 
Berdasarkan pada gambaran keadaan di atas, penelitian ini membahas mengenai model dampak dan keberlanjutan pariwisata di Pulau Merah. Penelitian yang serupa sebelumnya telah dilakukan oleh (Chen, 2018) dan (Dwipayana, dkk., 2018), dengan hasil dari Chen menunjukkan bahwa SEM dapat diaplikasikan dalam model pengaruh emosi guru terhadap pendekatan pengajaran yang digunakannya, sedangkan Dwipayana menunjukkan hasil berupa model dampak dan keberlanjutan pariwisata pesisir di Kabupaten Badung yang memenuhi uji kelayakan dan menjawab hipotesis penelitian yang menunjukkan hubungan korelasional dan kausal antar variabelnya.

Model dalam penelitian ini merupakan aplikasi dari Structural Equation Model (SEM). Model yang dibentuk dievaluasi kelayakannya dengan ketentuan dalan uji Goodness of Fit. Dampak pariwisata dilihat dari pendapat masyarakat sekitar yang terlibat dalam kegiatan kepariwisataan di Pulau Merah melalui pengisian kuesioner.

\section{Tinjauan Pustaka}

Menurut Undang-Undang No.10 Tahun 2009 tentang Kepariwisataan menyebutkan pengertian objek wisata atau daya tarik wisata adalah segala sesuatu yang memiliki keunikan, keindahan, dan nilai yang berupa keanekaragaman kekayaan alam, budaya, dan hasil buatan manusia yang menjadi sasaran atau tujuan kunjungan wisatawan. Dalam memenuhi kebutuhan wisatawan, suatu objek wisata harus didukung oleh empat komponen utama yang dikenal dengan komponen 4A yaitu: atraksi, fasilitas, aksesibilitas, dan pelayanan tambahan (Cooper, 1993) dalam (Suwena dan Widyatmaja, 2017). Sebagai akibat dari keberadaan suatu objek wisata tentu memiliki dampak terhadap lingkungan sekitar. Dampak yang dimaksudkan dapat berupa dampak positif maupun dampak negatif atas munculnya suatu kegiatan kepariwisataan dan juga meningkatnya jumlah wisatawan. Pariwisata berkelanjutan adalah konsep yang mengedepankan pemberdayaan dan optimalisasi manfaat kepariwisataan bagi masyarakat dan pelestarian lingkungan baik 
lingkungan fisik maupun lingkungan non fisik di destinasi (Sunaryo, 2013). Prinsip dari model pembangunan kepariwisataan berlanjut dan berwawasan lingkungan adalah mengukur kinerja pembangunan kepariwisataan melalui manfaat dari beberapa aspek, yaitu manfaat ekonomi, manfaat sosial budaya, dan manfaat lingkungan.

\section{Metode Penelitian}

Penelitian ini terdiri atas 4 (empat) tahapan, yaitu tahap pertama adalah observasi yang dilakukan untuk mengetahui kondisi Pulau Merah saat ini baik melalui pengamatan maupun wawancara. Tahap kedua adalah pengambilan data yang dilakukan melalui penyebaran kuesioner. Pengambilan responden sebagai sampel menggunakan teknik purposive sampling. Purposive sampling adalah teknik penentuan sampel yang dilakukan dengan menggunakan pertimbangan tertentu (Sugitono, 2017). Pertimbangan yang digunakan pada pengambilan data ini adalah responden merupakan warga Desa Sumberagung yang terlibat dalam kegiatan pengelolaan Pulau Merah. Berdasarkan pada data yang ada, diketahui bahwa jumlah populasi sebanyak 241 orang dengan rincian 65 orang anggota Pokmas, 101 orang pengusaha warung, 20 orang pengusaha sewa payung pantai, 6 orang pengusaha jasa penyedia toilet, dan 49 orang pengusaha homestay. Ketentuan banyaknya jumlah responden yang digunakan adalah sebanyak minimal 100 orang (Ferdinand, 2014), dan pada penelitian ini diambil sebanyak 110 responden. Tahap ketiga adalah analisis data yang telah diperoleh pada tahapan sebelumnya. Analisis data yang dilakukan meliputi uji instrumen, uji asumsi SEM, dan selanjutnya melakukan uji Goodness of Fit untuk melihat kelayakan model melalui kriteria ChiSquare, RMSEA, GFI, CMIN/DF, TLI, dan CFI. Tahap keempat adalah penarikan kesimpulan, yang merupakan tahapan dimana hasil analisis yang diperoleh diinterpretasikan dan digunakan untuk penarikan kesimpulan. 


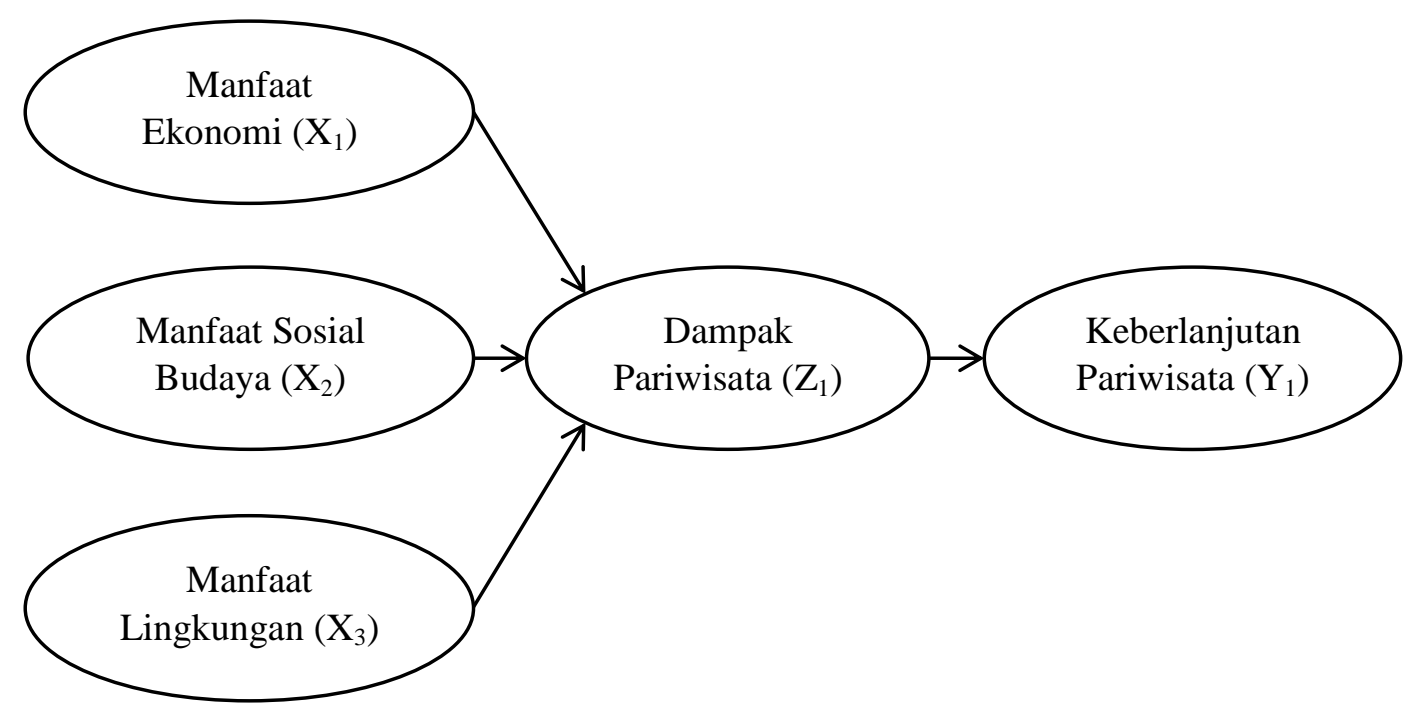

Gambar 1. Model Hubungan Antar Variabel

Pada penelitian ini terdapat 5 buah variabel yang terlibat, dimana hubungan antar variabel ditunjukkan seperti pada gambar 1 . Model hubungan antar variabel pada gambar 1 selanjutnya dibentuk dalam perangkat lunak AMOS untuk dilakukan analisis.

\section{Hasil dan Pembahasan}

\section{Profil Responden}

Responden dalam penelitian ini didominasi oleh laki-laki dengan persentase yang dicapai sebesar 53,6\% dan keseluruhan responden merupakan masyarakat Desa Sumberagung yang merupakan daerah letak objek wisata Pulau Merah berada. Pada karakteristik usia, responden didominasi oleh rentang usia antara 25-44 tahun dengan persentase sebesar $45 \%$. Berdasarkan pada latar belakang pekerjaan yang dimiliki, pekerjaan responden lebih banyak sebagai wiraswasta dengan persentase sebesar $48,2 \%$. Pekerjaan yang dimaksud dalam hal ini merupakan pekerjaan yang diyakini oleh responden sebagai sumber mata pencaharian utamanya. Berdasarkan pada bentuk kontribusi yang diberikan masyarakat dalam kegiatan kepariwisataan di Pulau Merah, kontribusi terbesar adalah dengan membuka warung yang 
mencapai persentase sebesar 34,5\%. Selain itu, berdasarkan pada lamanya waktu kontribusi 58,2\% responden mulai ikut berkontribusi sejak rentang waktu 0-5 tahun terakhir.

\section{Uji Instrumen}

Uji instrumen dalam penelitian ini dilakukan untuk mengetahui kelayakan kuesioner sebagai alat untuk melakukan pengambilan data. Uji instrumen yang dilakukan meliputi 2 bentuk uji, yaitu uji validitas dan reliabilitas instrumen dan dilakukan dengan menggunakan bantuan perangkat lunak SPSS. Uji validitas pada penelitian ini dilakukan dengan mengamati nilai signifikansi, dengan ketentuan signifikansi < 0,05 dan dinyatakan valis. Intrumen yang baik haruslah memenuhi syarat validitas. Hasil uji validitas ditunjukkan dalam tabel berikut.

Tabel 3. Hasil Uji Validitas

\begin{tabular}{|c|c|c|c|c|}
\hline Variabel & Indikator & $\begin{array}{l}\text { Sig. } \\
\text { (2-tailed) }\end{array}$ & $\mathbf{N}$ & Keterangan \\
\hline \multirow{7}{*}{$\begin{array}{l}\text { Manfaat } \\
\text { Ekonomi } \\
\left(X_{1}\right)\end{array}$} & $\mathrm{X}_{1.1}$ Pelatihan kepariwisataan berkala & 0,000 & 110 & Valid \\
\hline & $\mathrm{X}_{1.2}$ Peningkatan partisipasi masyarakat & 0,000 & 110 & Valid \\
\hline & $\mathrm{X}_{1.3}$ Partisipasi bermanfaat secara ekonomi & 0,000 & 110 & Valid \\
\hline & $\mathrm{X}_{1.4}$ Penyerapan tenaga kerja & 0,000 & 110 & Valid \\
\hline & $\begin{array}{l}\mathrm{X}_{1.5} \text { Pekerjaan masyarakat mendukung } \\
\text { kegiatan kepariwisataan }\end{array}$ & 0,000 & 110 & Valid \\
\hline & $\begin{array}{l}\mathrm{X}_{1.6} \text { Memperoleh penghasilan dari kegiatan } \\
\text { kepariwisataan }\end{array}$ & 0,000 & 110 & Valid \\
\hline & $\begin{array}{l}\mathrm{X}_{1.7} \text { Pendapatan kegiatan kepariwisataan } \\
\text { lebih besar }\end{array}$ & 0,000 & 110 & Valid \\
\hline Manfaat & $\begin{array}{l}\mathrm{X}_{2.1} \text { Kegiatan wisata memoerhatikan adat } \\
\text { istiadat }\end{array}$ & 0,000 & 110 & Valid \\
\hline Budaya $\left(X_{2}\right)$ & $\begin{array}{l}\mathrm{X}_{2.2} \text { Adanya objek wisata mengurangi } \\
\text { kriminalitas }\end{array}$ & 0,000 & 110 & Valid \\
\hline
\end{tabular}




\begin{tabular}{|c|c|c|c|c|}
\hline & $\begin{array}{l}\mathrm{X}_{2.3} \text { Keterlibatan masyarakat menurunkan } \\
\text { kriminalitas }\end{array}$ & 0,000 & 110 & Valid \\
\hline \multirow{6}{*}{$\begin{array}{l}\text { Manfaat } \\
\text { Lingkunga } \\
n\left(X_{3}\right)\end{array}$} & $\mathrm{X}_{3.1}$ Lingkungan lestari & 0,000 & 110 & Valid \\
\hline & $\mathrm{X}_{3.2}$ Fasilitas umum bertambah & 0,000 & 110 & Valid \\
\hline & $\mathrm{X}_{3.3}$ Kualitas fasilitas umum baik & 0,000 & 110 & Valid \\
\hline & $\mathrm{X}_{3.4}$ Area sekitar objek tertata & 0,000 & 110 & Valid \\
\hline & $\mathrm{X}_{3.5}$ Kawasan sekitar pesisir indah & 0,000 & 110 & Valid \\
\hline & $\mathrm{X}_{3.6}$ Sampah terkelola dengan baik & 0,000 & 110 & Valid \\
\hline \multirow{5}{*}{$\begin{array}{l}\text { Dampak } \\
\text { Pariwisata } \\
\left(\mathrm{Z}_{1}\right)\end{array}$} & $\begin{array}{l}\mathrm{Z}_{1.1} \text { Kegiatan pariwisata sumber } \\
\text { perekonomian }\end{array}$ & 0,000 & 110 & Valid \\
\hline & $\mathrm{Z}_{1.2}$ Harga properti meningkat & 0,000 & 110 & Valid \\
\hline & Z1.3 Harga barang naik & 0,000 & 110 & Valid \\
\hline & $Z_{1.4}$ Kesejahteraan meningkat & 0,000 & 110 & Valid \\
\hline & $\begin{array}{l}\text { Z1.5 Kegiatan pariwisata didukung } \\
\text { masyarakat }\end{array}$ & 0,000 & 110 & Valid \\
\hline \multirow{4}{*}{$\begin{array}{l}\text { Keberlanjut } \\
\text { an } \\
\text { Pariwisata } \\
\left(\mathrm{Y}_{1}\right)\end{array}$} & $\mathrm{Y}_{1.1}$ Pelayanan publik meningkat & 0,000 & 110 & Valid \\
\hline & $\begin{array}{l}\text { Y1.2 Kegiatan pariwisata memperhatikan } \\
\text { kearifan lokal }\end{array}$ & 0,000 & 110 & Valid \\
\hline & $\mathrm{Y}_{1.3}$ Pelestarian lingkungan berkala & 0,000 & 110 & Valid \\
\hline & $\begin{array}{l}\text { Y1.4 Masyarakat semakin paham tentang } \\
\text { pariwisata }\end{array}$ & 0,000 & 110 & Valid \\
\hline
\end{tabular}

Berdasarkan pada tabel 3 setiap butir instrumen memiliki nilai signifikansi lebih kecil dari 0,05 sehingga instrument dinyatakan valid. Uji reliabilitas pada penelitian ini dilakukan untuk mengetahui konsistensi dari instrument penelitian jika diguankan dalam waktu yang berbeda pada subjek yang sama. Instrumen yang baik harus memenuhi reliabilitas, yang ditunjukkan dengan nilai Cronbach's Alpha lebih besar dari 0,60. Hasil uji reliabilitas instrument ditunjukkan dalam tabel berikut. 
Tabel 4. Hasil Uji Reliabilitas

\begin{tabular}{llll}
\hline Variabel & Nilai & & \\
& Cronbach's & N of items & Keterangan \\
& Alpha & & \\
\hline Manfaat Ekonomi $\left(\mathrm{X}_{1}\right)$ & 0,715 & 7 & Reliabel \\
\hline Manfaat Sosial Budaya $\left(\mathrm{X}_{2}\right)$ & 0,627 & 3 & Reliabel \\
\hline Manfaat Lingkungan $\left(\mathrm{X}_{3}\right)$ & 0,723 & 6 & Reliabel \\
\hline Dampak Pariwisata $\left(\mathrm{Z}_{1}\right)$ & 0,676 & 5 & Reliabel \\
\hline Keberlanjutan Pariwisata & 0,706 & 4 & Reliabel \\
$\left(Y_{1}\right)$ & & & \\
\hline
\end{tabular}

Berdasarkan pada tabel 4 dapat diketahui bahwa nilai Cronbach's Alpha untuk setiap variabel bernilai di atas 0,60 , hal tersebut menunjukkan bahwa instrumen penelitian dinyatakan reliabel.

\section{Uji Asumsi SEM}

Uji asumsi SEM dalam penelitian ini dilakukan untuk memenuhi syarat dalam prosedur pengumpulan dan pengolahan data yang dianalisis dengan menggunakan pemodelan SEM. Beberapa asumsi yang harus dipenuhi diantaranya adalah normalitas, outliers, dan multicollinearity.

Pada uji normalitas digunakan perangkat lunak AMOS dengan memperhatikan nilai c.r. (critical ratio) pada skewness value (nilai dari tingkat kemencengan) pada output, jika nilai c.r. berada pada rentang nilai $\pm 2,58$ maka data dikatakan berdistribusi normal. Data yang baik adalah memenuhi distribusi normal. Hasil uji normalitas ditunjukkan pada tabel berikut. 
Tabel 5. Hasil Uji Normalitas

\begin{tabular}{|c|c|c|c|c|c|c|}
\hline Variable & $\min$ & $\max$ & skew & c.r. & kurtosis & c.r. \\
\hline Y1.4 & 3,000 & 5,000 &,- 470 & $-2,013$ & $-1,083$ & $-2,319$ \\
\hline Y1.3 & 2,000 & 5,000 &,- 382 & $-1,637$ &,- 272 &,- 583 \\
\hline Y1.2 & 3,000 & 5,000 &,- 198 &,- 849 &,- 837 & $-1,792$ \\
\hline Y1.1 & 2,000 & 5,000 &,- 717 & $-2,071$ &, 503 & 1,077 \\
\hline Z1.5 & 3,000 & 5,000 &,- 124 &,- 531 &,- 495 & $-1,060$ \\
\hline Z1.4 & 2,000 & 5,000 & 257 & 1,101 &,- 154 &,- 331 \\
\hline Z1.3 & 1,000 & 5,000 & ,579 & 2,477 & $-1,020$ & $-2,183$ \\
\hline $\mathrm{Z} 1.2$ & 3,000 & 5,000 &,- 442 & $-1,891$ &,- 660 & $-1,414$ \\
\hline Z1.1 & 2,000 & 5,000 & ,227 & ,971 & $-1,063$ & $-2,276$ \\
\hline X3.6 & 3,000 & 5,000 &,- 270 & $-1,156$ &,- 968 & $-2,072$ \\
\hline X3.5 & 3,000 & 5,000 &,- 006 &,- 026 &,- 105 &,- 224 \\
\hline X3.4 & 1,000 & 5,000 &,- 526 & $-2,253$ &,- 471 & $-1,009$ \\
\hline X3.3 & 2,000 & 5,000 &,- 173 &,- 741 &,- 109 &,- 234 \\
\hline X3.2 & 2,000 & 5,000 &,- 379 & $-1,624$ & ,407 & 872 \\
\hline X3.1 & 3,000 & 5,000 & ,027 & ,118 &,- 657 & $-1,407$ \\
\hline $\mathrm{X} 2.3$ & 2,000 & 5,000 & ,056 & 240 & $-1,421$ & $-2,043$ \\
\hline $\mathrm{X} 2.2$ & 2,000 & 5,000 & ,123 & ,525 & $-1,033$ & $-2,213$ \\
\hline $\mathrm{X} 2.1$ & 3,000 & 5,000 &,- 931 & $-2,086$ &,- 604 & $-1,293$ \\
\hline
\end{tabular}




\begin{tabular}{lllllll}
\hline Variable & min & max & skew & c.r. & kurtosis & c.r. \\
\hline X1.7 & 2,000 & 5,000 &,- 796 & $-2,408$ &,- 124 &,- 266 \\
\hline X1.6 & 2,000 & 5,000 &, 013 &, 058 &,- 649 & $-1,389$ \\
\hline X1.5 & 2,000 & 5,000 &, 582 & 2,490 &,- 721 & $-1,544$ \\
\hline X1.4 & 2,000 & 5,000 &,- 549 & $-2,349$ &, 547 & 1,172 \\
\hline X1.3 & 2,000 & 5,000 &,- 475 & $-2,036$ &,- 306 &,- 655 \\
\hline X1.2 & 2,000 & 5,000 &,- 135 &,- 579 &,- 597 & $-1,278$ \\
\hline$X 1.1$ & 2,000 & 5,000 &,- 710 & $-2,038$ &,- 286 &,- 611 \\
\hline
\end{tabular}

Berdasarkan pada tabel 5 dapat dilihat bahwa untuk c.r. tidak ada yang memiliki nilai di luar rentang $\pm 2,58$. Hal ini menunjukkan bahwa data pada penelitian ini dinyatakan normal dan telah memenuhi syarat uji normalitas.

Pada uji outliers digunakan perangkat lunak AMOS dengan memperhatikan nilai jarak mahalanobis (the mahalanobis distance) untuk setiap data yang ada. Data yang baik adalah tidak memiliki outliers dengan ketentuan jarak mahalanobis seluruh pengamatan harus di bawah nilai $\operatorname{Chi-Square}\left(\chi^{2}\right)$ yaitu sebesar $\chi_{0,05 ; 108}^{2}=$ 133,257. Berdasarkan pada hasil uji outliers diperoleh bahwa jarak mahalanobis tertinggi yang dicapai adalah 45,471. Nilai tersebut tidak melampaui nilai $\chi^{2}$ sehingga dikatakan tidak ada outliers.

Pada uji multicollinearity digunakan perangkat lunak SPSS dengan memperhatikan nilai Tolerance dan Variance Inflation Factor (VIF). Data yang baik adalah bebas multicollinearity, dimana ketentuan bebas multicollinearity adalah jika Tollerance $\geq 0,10$ sedangkan VIF $\leq 10$. Hasil uji multicollinearity ditunjukkan pada tabel berikut. 
Tabel 6. Hasil Uji Multicollinearity

\begin{tabular}{|c|c|c|c|c|c|c|c|c|}
\hline \multirow[b]{4}{*}{ Mode } & \multicolumn{8}{|c|}{ Standardiz } \\
\hline & & \multicolumn{5}{|c|}{ Unstandardizeed } & \multicolumn{2}{|c|}{ Collinearity } \\
\hline & & \multicolumn{2}{|c|}{ d Coefficients } & \multicolumn{2}{|l|}{ Coefficientst } & \multirow[t]{2}{*}{ Sig. } & \multicolumn{2}{|l|}{ Statistics } \\
\hline & & B & Error & Beta & & & Tolerance & VIF \\
\hline \multirow[t]{5}{*}{1} & (Constant) & 9.230 & 2,370 & & 3,895 & 0,000 & & \\
\hline & $\overline{\text { TOTAL_X }}$ & 30,034 & 0,064 & 0,044 & 0,526 & 0,600 & 0,970 & 1,031 \\
\hline & TOTAL_X & 20,327 & 0,068 & 0,430 & 4,818 & 0,000 & 0,854 & 1,171 \\
\hline & $\overline{\text { TOTAL_X }}$ & 10,145 & 0,093 & 0,142 & 1,561 & 0,121 & 0,829 & 1,207 \\
\hline & TOTAL_Z & $1-0,101$ & 0,053 & $-0,160$ & $-1,896$ & 0,061 & 0,961 & 1,040 \\
\hline
\end{tabular}

a. Dependent Variable: TOTAL_Y1

Berdasarkan pada tabel 6 diketahui bahwa nilai Tollerance untuk setiap variabel bebas $\geq 0,10$ sedangkan nilai VIF $\leq 10$. Hal ini menunjukkan bahwa data dinyatakan bebas multicollinearity.

\section{Analisis Kelayakan Model}

Analisis Struktural Equation Model (SEM) secara full model dilakukan untuk menguji model yang dikembangkan dalam penelitian ini. Pengujian model dalam SEM dilakukan dengan uji kesesuaian model. Adapun hasil pengolahan data pada full model ditunjukkan pada gambar berikut ini: 


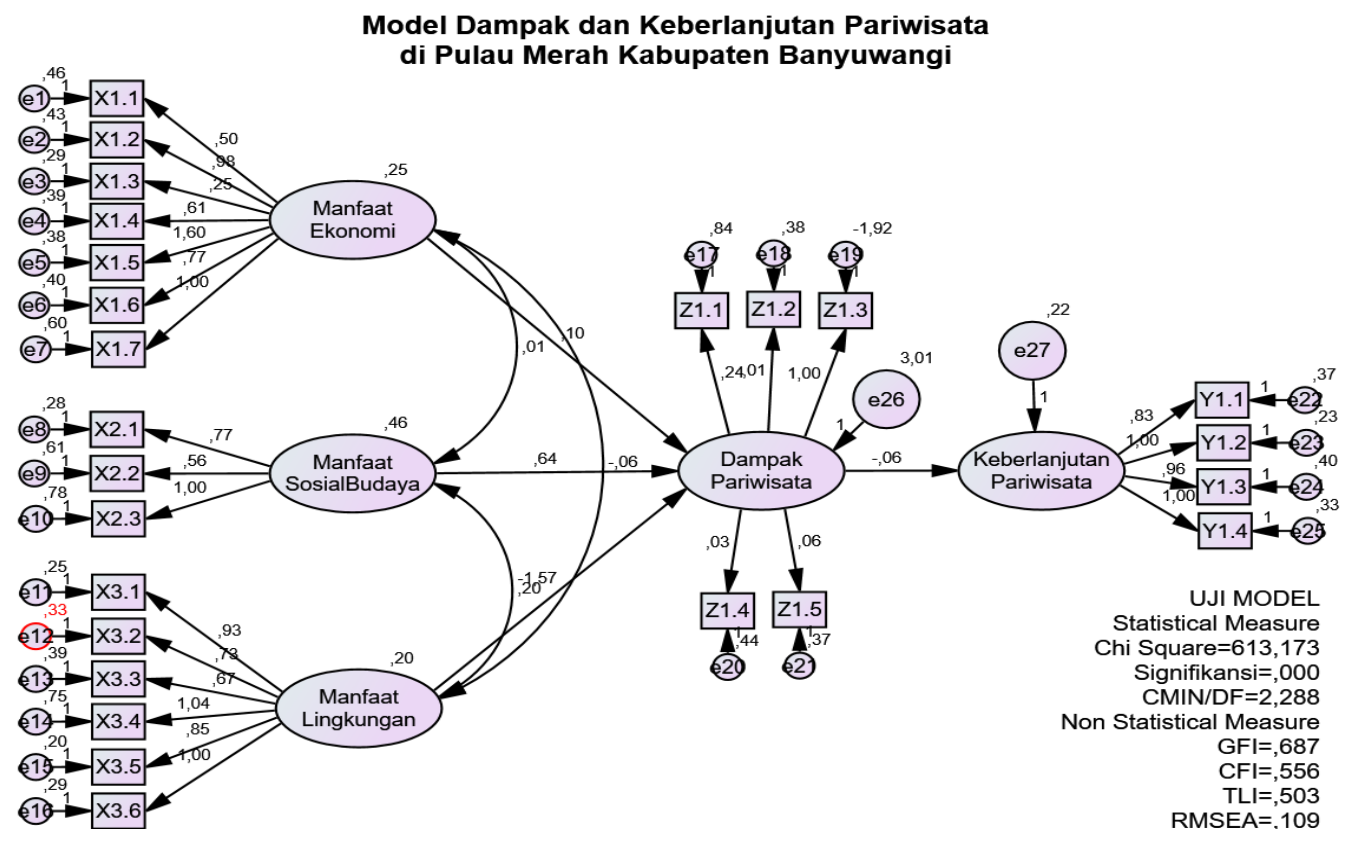

Gambar 2. Analisis Full Model

Hasil pengujian full model pada gambar di atas dievaluasi kelayakan SEM dengan cara membandingkan nilai hasil olah data dan nilai cut-off value. Hasil dari perbandingan tersebut lebih jelas ditunjukkan pada tabel berikut.

Tabel 7. Hasil Pengujian Full Model

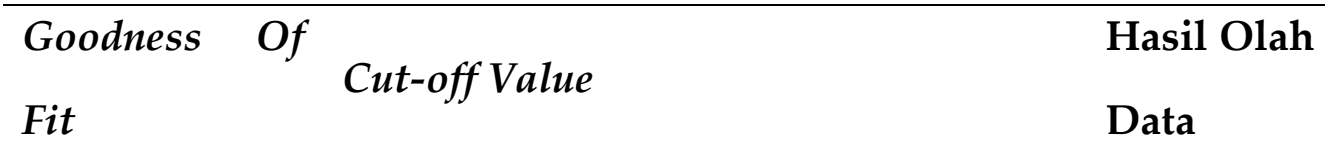

Chi-Square $\left(\chi^{2}\right) \quad$ Diharapkan kecil $(<133,257) \quad 613,173$

\begin{tabular}{ll}
\hline Significance & $\geq 0,05$ \\
Probability & 0,000
\end{tabular}

\begin{tabular}{lcc}
\hline RMSEA & $\leq 0,08$ & 0,109 \\
\hline CMIN/DF & $\leq 2,00$ & 2,288 \\
\hline GFI & $0<G F I<1 ; \geq 0,90=$ good fit & 0,687 \\
\hline TLI & $0<T L I<1 ; \geq 0,90=$ good fit & 0,503
\end{tabular}




CFI $\quad 0<C F I<1 ; \geq 0,90=$ good fit $\quad 0,556$

Berdasarkan pada tabel 7 maka pengujian kelayakan Full Model diketahui bahwa probabilitas model 0,000 dengan Chi-Square yang cukup besar dan melampaui nilai chi-square hitung. Hal ini menunjukkan bahwa model tidak fit. Selain itu, beberapa kriteria hasil olah data tidak memenuhi cut-of value dari goodness of fit index yang disyaratkan sehingga dapat dinyatakan model tidak fit.

Model pada gambar 2 dapat dilakukan perbaikan dengan memanfaatkan informasi yang tertera dalam modification indices. Hasil pengujian full model setelah dilakukan perbaikan ditunjukkan pada tabel berikut.

Tabel 8. Hasil Pengujian Full Model setelah Dilakukan Perbaikan

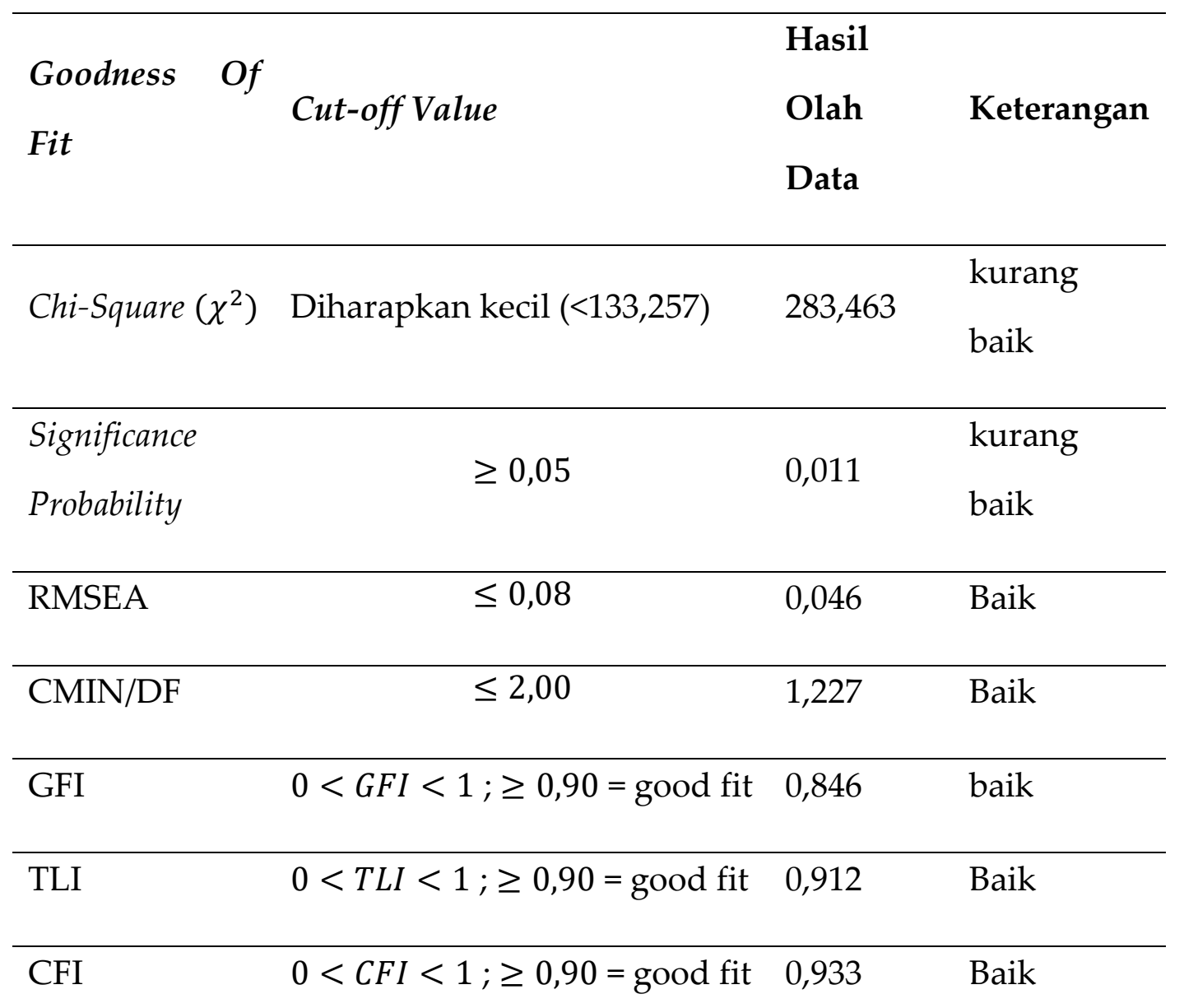


Berdasarkan pada hasil pengujian pada tabel 8 di atas diketahui bahwa nilai RMSEA, CMIN/DF, TLI, CFI telah melampaui nilai cut-off value sehingga dinyatakan baik, dan untuk nilai GFI sebesar 0,846 belum melampaui nilai cut-off value akan tetapi nilai ini masih berada dalam interval antara 0 dengan 1 serta mendekati nilai cut-off value yaitu 0,90 oleh karena itu GFI juga dapat dinyatakan baik. Sedangkan untuk nilai chi-square dinyatakan kurang baik karena memiliki nilai yang masih melampaui batas maksimal nilai chi-square hitung yaitu 133,257 akan tetapi dalam model yang diperbaiki nilai ini telah menunjukkan pengurangan dibandingkan dengan model sebelumnya. Begitu pula dengan nilai significance probability yang masih kurang baik karena menunjukkan nilai yang belum melampaui 0,05 akan tetapi dalam model yang telah diperbaiki nilai ini juga menunjukkan adanya kenaikan dibandingkan dengan model sebelumnya. Berdasarkan pada informasi bahwa model yang diperbaiki telah memenuhi 5 (lima) dari 7 (tujuh) ukuran goodness of fit, maka secara keseluruhan model SEM ini dapat dikatakan baik dan memenuhi kriteria kelayakan sebuah model.

\section{Kesimpulan}

Kesimpulan dalam penelitian ini adalah model SEM untuk dampak dan keberlanjutan pariwisata di objek wisata Pulau Merah telah dinyatakan layak berdasarkan pada hasil uji Goodness of Fit. Selain itu, dalam pembentukan model SEM ini terlebih dahulu dilakukan pengujian baik untuk instrumen maupun asumsi-asumsi yang harus dipenuhi. Berdasarkan pada hasil pengujian, dapat dinyatakan instrumen yang digunakan dalam pengambilan data dinyatakan layak (valid dan reliabel), selain itu asumsi yang dipersyaratkan juga telah dipenuhi yaitu memenuhi data berdistribusi normal, tidak terdapat outliers, dan bebas multicollinearity. 


\section{Ucapan Terima Kasih}

Riset ini dibiayai oleh Politeknik Negeri Banyuwangi (Poliwangi) pada tahun anggaran 2019. Untuk itu ucapan terima kasih disampaikan kepada Direktur Poliwangi dan juga Ketua Pusat Penelitian dan Pengabdian Masyarakat (PPPM) Poliwangi yang telah bersedia untuk membantu sehingga riset ini dapat terselesaikan tepat waktu. Selain itu terimakasih juga disampaikan kepada tim peneliti yang telah menyediakan waktu untuk menyelesaikan tanggungjawab riset ini, serta kepada responden yang terlibat karena telah bersedia memberikan data yang berguna untuk bahan riset ini.

\section{Daftar Pustaka}

Chen, Junjun. 2018. Exploring the Impact of Teacher Emotions on Their Approaches to Teaching: A Structural Equation Modelling Approach. www.wileyonlinelibrary.com:British Journal of Educational Psychology. 89. (57-74).

Cooper et. al. 1993. Tourism Principles \& Practice. England : Longman Group Limited.

Dwipayana, N.P. Kencana, E.N. Tastrawati, N.K.T. 2018. Memodelkan Dampak dan Keberlanjutan Pariwisata Pesisir di Kabupaten Badung-Provinsi Bali. E-Journal Matematika. 7(2): 111-121.

Ferdinand, Augusty. 2014. Structural equation Modeling dalam Penelitian Manajemen. Semarang: BP Undip-Undip Press.

Butler, R.W. 2011. Tourism Area Life Cycle.Contemporary Tourism Reviews. Woodeaton: Goodfellow Publishers Limited.

Sugiyono. 2017. Metode Penelitian Bisnis Pendekatan Kuantitaif, Kualitatif, Kombinasi, dan R\&D. Bandung: Alfabeta.

Sunaryo, Bambang. 2013. Kebijakan Pembangunan Destinasi Pariwisata: Konsep dan Aplikasinya di Indonesia. Yogyakarta: Gava Media.

Suwena, I Ketut dan Widyatmaja, I Gst Ngr. 2017. Pengetahuan Dasar Ilmu Pariwisata. Denpasar: Pustaka Larasan. 


\section{Profil Penulis}

Aprilia Divi Yustita, S.Si., M.Si. adalah dosen Program Studi Manajemen Bisnis Pariwisata, Politeknik Negeri Banyuwangi sejak tahun 2016 hingga sekarang. Ia menyelesaikan program sarjananya di Fakultas MIPA Universitas Brawijaya tahun 2014, dan program magister di Fakultas MIPA Institut Teknologi Sepuluh Nopember Surabaya tahun 2016.

Siska Aprilia Hardiyanti, S.Pd., M.Si. adalah dosen Program Studi Teknik Sipil, Politeknik Negeri Banyuwangi sejak tahun 2016 hingga sekarang. Ia menyelesaikan program sarjananya di Jurusan Pendidikan Matematika, Fakultas Keguruan dan Ilmu Pendidikan (FKIP) Universitas Jember tahun 2014, dan program magister di Fakultas MIPA Institut Teknologi Sepuluh Nopember Surabaya tahun 2016.

Ayu Purwaningtyas, S.Hut., M.M, adalah Dosen Program Studi Manajemen Bisnis Pariwisata, Politeknik Negeri Banyuwangi mulai dari tahun 2018 sampai dengan sekarang. Lulusan program sarjana Fakultas Kehutanan Institut Pertanian Bogor tahun 2010 dan program magister manajemen Universitas Jember tahun 2017. 